\title{
Conference report
}

Обзор конференции

DOI 10.31696/2618-7043-2019-2-4-1063-1080

Обзорная статья

УДК $82.091=411.21$

Review

\section{На арабской митературоведческой конференции (Рабат, сентябрь 2018 г.)}

\author{
Д. В. Микульский \\ Институт востоковедения РАН, г. Москва, Российская Федерация \\ ORCID: https://orcid.org/0000-0002-3239-1670; e-mail: dmitri_mikulski@mail.ru
}

Резюме: статья посвящена Пятнадцатой Шарджийской литературоведческой конференции, которая проводилась в сентябре 2018 г. в столице Марокко Рабате. Автор рассказывает о том, как была организована эта научная встреча, о некоторых из ее участников, излагает научные проблемы, которые были на ней затронуты. Самое интересное в статье - это пересказ бесед автора с его новыми знакомыми, арабскими писателями и литературоведами. Арабские коллеги поведали Д. В. Микульскому о своем отношении к России и российской арабистике, о проблемах взаимодействия Арабского мира и Запада. Разумеется, арабские интеллектуалы не могли обойти молчанием родное словесное наследие, которое является для них живым предметом размышлений и неоскудевающим источником духовной пищи. Статья дает яркое представление о думах наших арабских коллег.

Ключевые слова: арабская классическая словесность; арабская литература; арабский роман; арабское литературоведение; Россия и Арабский мир; Шарджийские конференции

Аля цитирования: Микульский Д. В. На арабской литературоведческой конференции (Рабат, сентябрь 2018 г.). Ориенталистика. 2019;2(4):1063-1080. DOI: 10.31696/2618-7043-2019-2-4-1063-1080.

\section{At an Arabic academic conference on the study of contemporary Arabic literature (Rabat, September 2018)}

\author{
D. V. Mikulskiy \\ Institute of Oriental Studies, Russian Academy of Sciences, Moscow, Russian Federation \\ ORCID: https://orcid.org/0000-0002-3239-1670; e-mail: dmitri_mikulski@mail.ru
}

Abstract: the article comprises a report of the 15-th Sharjah conference on
contemporary Arabic literature held in Rabat (Morocco) in September 2018. The
author, Professor Mikulski (Moscow) provides in detail the list of topics discussed as
(C) (i) Контент доступен под лицензией Creative Commons Attribution 4.0 License. 
well as the history of the meeting, which dates back to 2003. The innovative aspect of the present report are the informal interviews taken by Professor Mikulski from some of the most prominent participants. These interviews comprise a number of aspects among which are the personal views on Russia and the Russian traditions of Arabic studies, as well as their concepts of historical and cultural relations between the Arab countries and the West. Of course, the Arab intellectuals could not help to ignore the classical Arabic literary legacy, which continues to be their constant object of cultural and literary reflections and the inexhaustible source of mental pabulum. The article presents a vivid image of the thoughts and views of our Arab colleagues.

Keywords: Arabs, literature, classical; Arabs, literature, study of; Arabs, world of; novel, Arabic; Russia; Sarjah, conferences of

For citation: Mikulskiy D. V. At an Arabic academic conference on the study of contemporary Arabic literature (Rabat, September 2018). Orientalistica. 2019;2(4):1063-1080. (In Russ.). DOI: 10.31696/2618-7043-2019-2-4-1063-1080.

Любовь арабов к словесному искусству широко известна и объяснима. Ведь когда-то, еще в доисламскую эпоху, времена «языческого невежества» (ал-джахилиййа), арабам - и кочевникам, и оседлым - был доступен лишь один род творчества - знаменитая доисламская поэзия, ставшая впоследствии основой словесного искусства не только арабских народов, сложившихся на территориях, завоеванных в VII-VIII вв. арабами-мусульманами, но и литератур большинства этносов, принявших ислам, но сохранивших национальную самость.

Еще в ту легендарную доисламскую эпоху появились первые арабские меценаты, богато вознаграждавшие одержимых джиннами стихотворцев за явленное ими поэтическое искусство, порожденное творческим вдохновением.

В современном Арабском мире живо не только литературное творчество, но и традиция морального и материального поощрения писателей. Одной из форм, с одной стороны, общения арабских литераторов ${ }^{1}$, а с другой - всяческого поощрения литературного творчества, являются ежегодные писательские и одновременно литературно-критические конференции писателей и литературоведов, которые получили наименование Шарджийских встреч.

Дело в том, что в состав федерации Объединенных Арабских Эмиратов (OАР) входит эмират Шарджа, который занимает среди прочих монархий - членов федерации ОАР - третье место по размеру территории и численности населения. Среди многих продолжающихся культурных мероприятий, которые проводятся по инициативе правительства эмирата Шарджа, видное место занимает литературно-крити-

${ }^{1}$ Заметим, что такое общение имеет давнюю традицию. Арабские стихотворцы собирались, чтобы послушать произведения друг друга и обменяться мнениями, еще в ту самую блистательную эпоху ал-джахилиййи, например, на знаменитой ярмарке в 'Указе, что под Меккой. 
ческая конференция, о которой идет речь. Мне посчастливилось принять участие в 15-й подобной встрече. Насколько мне известно, решение о проведении таких конференций было принято правительством эмирата Шарджа в 2003 г. Инициаторы этих регулярно проводимых конференций, среди которых ведущую роль сыграл правитель эмирата Его Высочество доктор Султан б. Мухаммад ал-Касими (род. 1939; находится во главе эмирата Шарджа с 1972 г.), видный деятель современной арабской культуры, поставили перед их организаторами благородную задачу способствовать развитию современного арабского литературного процесса, оказывать всемерную поддержку арабским писателям, критикам, литературоведам и прочим труженикам на ниве творческой работы ${ }^{2}$.

Есть основания полагать, что первоначально конференции проводились в Шардже, но эмир Султан б. Мухаммад принял решение о том, чтобы арабские литераторы собирались в важнейших в культурном отношении городах Арабского мира. Начало осуществлению этого решения было положено в 2010 г., когда 7-я Шарджийская встреча была созвана в знаменитом египетском историческом городе Луксоре $[2$, с. 1]. Встреча же, в которой довелось принять участие мне, проходила в столице Марокко Рабате 18-20 сентября 2018 г.

Основную роль в проведении этих форумов играет Департамент по делам культуры правительства эмирата Шарджа, возглавляемый господином 'Абдаллахом Мухаммадом ал-'Увайсом. Насколько я могу судить, помимо коренных шарджийцев, в Департаменте трудятся и выходцы из других арабских стран, в том числе из Египта.

Прежде всего, должен отметить прекрасную информационно-организационную подготовку мероприятия, в котором я участвовал. Помимо подробной программы, организаторы издали брошюру, содержащую сведения обо всех участниках конференции [2, с. 1], а также целый том с текстами докладов, которые должны были быть на ней прочитаны [3]. Это свидетельствует о четкой и объемной организационной работе.

Планировалось, что в работе форума примут участие 36 арабских писателей (в том числе шестеро из ОАЭ и трое - арабские литераторы, проживающие за пределами Арабского мира, - США, Великобритания, Австрия). На конференцию были приглашены двадцать три арабских критика, литературоведа и издателя [2, с. 2-3].

Состав писателей, прибывших на форум и принявших в нем участие, указан в таблице.

${ }^{2}$ См. о правителе эмирата Шарджа и его роли в современной культурной жизни Арабского мира: [1, с. 344]. 
Арабские страны, представленные на форуме

\begin{tabular}{|c|l|c|}
\hline №/n & \multicolumn{1}{|c|}{ Страна } & Количество участников \\
\hline 1. & Марокко & 13 \\
\hline 2. & Тунис & 3 \\
\hline 3. & Египет & 3 \\
\hline 4. & Мавритания & 2 \\
\hline 5. & Кувейт & 2 \\
\hline 6. & Палестина & 1 \\
\hline 7. & Оман & 1 \\
\hline 8. & Ливан & 1 \\
\hline 9. & Саудовская Аравия & 1 \\
\hline
\end{tabular}

Понятное дело, что подобное представительство лишь отчасти соответствует, как мне представляется, реальной панораме литературного процесса в современном Арабском мире. Оказались не представлены такие весомые национальные арабские литературы, как алжирская (видимо, в силу сложных отношений между Марокко и Алжиром), суданская, ливийская, сирийская и иракская (повлияла, очевидно, непростая общественно-политическая ситуация в этих странах). Отсутствовали также представители иорданской литературы, но это, возможно, связано с тем, что форум 2019 г. планируется провести в столице Иордании Аммане. Участие только лишь одного ливанского представителя, видимо, объясняется некими «подводными течениями», и по той же причине слабо были представлены саудовская и оманская литературы.

Напротив, другие национальные арабские литературы оказались представлены более широко.

Значительное количество марокканских писателей, принявших участие в литературной встрече, объясняется тем, что Марокко - страна проведения конференции. Тунис и Мавритания - соседи Марокко, да к тому же тунисская литература имеет давние корни и в последние десятилетия успешно развивается. Египет - традиционный законодатель арабской литературной моды. Кувейт - сосед ОАЭ по Аравийскому полуострову.

В целом же надо отметить, что на форум были приглашены критики, литературоведы и издатели, происходившие и из иных арабских стран Бахрейна, Иордании, Йемена, Судана.

Будучи людьми широко, по-современному, мыслящими, а также уважающими традиции изучения арабской словесности на Западе (в широком смысле этого понятия, включая и Россию), устроители форума пригласили троих арабистов - профессора Краковского университета Барбару Михалек (Польша), профессора Хартмута Фандраша (ФРГ; к сожалению, он не смог лично принять участие) и автора этих строк. 
Из приводимых данных видно, что в конференции должны были принять участие 59 представителей различных арабских стран (собственно писателей, а также критиков и литературоведов). В гендерном отношении оказалось, что среди участников - 23 представительницы прекрасного пола (что составляет примерно $38,9 \%$ участников - для Арабского мира весьма существенный процент). Наиболее «открытыми» странами в этом отношении оказались ОАЭ (7 участниц), Марокко (6), Египет (2) и Кувейт (2). Тунис, Ливан, Палестина, Саудовская Аравия, Оман и Бахрейн представляли по одной участнице. Конечно, приведенные данные свидетельствуют о том, что и собственно литературное творчество, и его осмысление осуществляются женщинами не только в таких традиционно «эмансипированных» странах, как Марокко, Египет, Тунис, Ливан и Палестина, но и «за аравийской чадрой».

Всего в рамках форума было проведено 12 заседаний, на которых было прочитано около 20 докладов. Эти выступления посвящались следующим основным темам: эстетические особенности нового арабского романа, развитие техники романного письма, особенности романного жанра и его связи с другими видами искусств, интерактивный роман, новые явления в арабском романе [2, с. 73]. Был организован круглый стол на тему «Роман и его культурные особенности» (это мероприятие проходило 18 сентября на вечернем заседании [2, с. 75]).

Следует особо отметить, что на таком научном совещании общеарабского характера, каким была Шарджийская встреча, где мне довелось присутствовать, заседания и дискуссии велись на арабском литературном языке. На нем же в кулуарах общались между собою представители различных арабских стран (понятно, что их речь всегда была в той или иной степени окрашена элементами собственного родного диалекта). Если же вместе собирались несколько арабов-соотечественников, и представителей других арабских стран в их компании не было, то они с облегчением разговаривали между собою на родном диалекте. Точно так же все арабы-немарокканцы обращались к служащим отеля, в котором мы жили и где проходили заседания форума, - на своих родных диалектах и достигали, насколько я могу судить, полного взаимопонимания.

Возможно, что для современных марокканцев, в особенности среднего и старшего поколения, в роли языка, на котором следует общаться с выходцами из других арабских стран, а также с иностранцами-неарабами, говорящими по-арабски, выступает египетский диалект. Отвозивший меня в Касабланку (оттуда мне предстояло вернуться в Москву) немолодой таксист, приглашенный устроителями конференции, весьма подробно рассказал историю Касабланкского аэропорта имени Мухаммада V именно на египетском диалекте.

Как известно, современная языковая ситуация в Марокко отличается билингвизмом - сосуществованием арабского и французского языков. 
Проблема эта до сих пор весьма занимает образованных марокканцев. Мне довелось наблюдать жизненную ситуацию, которая объясняет, каким образом французский язык усваивается марокканцами с самого детства: однажды в фойе нашего отеля я видел девочку лет пяти, она раскрашивала книжку раскрасок, под картинками которой имелись подписи и по-арабски, и по-французски.

Слушая выступления арабских коллег, я с великим удовольствием отмечал упоминания имен наших великих литературоведов М. М. Бахтина и Ю. М. Лотмана. Отрадно было узнать, что, характеризуя поэтику романа, арабские литературоведы, критики и писатели оперируют понятием «многоголосье» (арабск. та'аддудиййат ал-асват), заимствованным из сочинений М. М. Бахтина.

Какие же проблемы современного романного творчества в Арабском мире обсуждались на конференции?

Роман - это самый изменчивый из литературных жанров, рамки которого практически безграничны, свободный и открытый.

В Арабском мире роман в современном смысле этого слова появился под западным влиянием. Первый арабский роман в собственном смысле этого слова - «Зейнаб» Хайкала.

В современной арабской литературе сложился так называемый новый роман, который, вместе с тем, в значительной мере и по содержанию, и по форме довольно традиционен, что стало привычным для современного читателя. Временная, эпохальная, граница рождения нового романа - 1991 г. (год распада Советского Союза). Ныне в Арабском мире наблюдается подлинный «взрыв» романного творчества.

Одним из истоков современного арабского романного творчества являются семейные воспоминания. Такой феномен в особенности характерен для литератур стран Залива. В связи с этим надо заметить, что данное обстоятельство хотя и относилось докладчиками к проблемам сугубо современным, с моей точки зрения, роднит этот пласт арабского романа с классической арабской исторической прозой, истоки которой коренятся в исторической памяти, порой носящей также и семейно-родственный характер.

В рамках арабского романного творчества сложился так называемый женский роман, что является и общественно, и академически вполне признанным явлением.

Современный арабский роман носит, главным образом, политикоидеологический характер.

Как бы то ни было, но искусство написания романа - это ремесло, которым современные молодые писатели должны всемерно овладевать и всячески оттачивать.

Пожалуй, самым необычным тематическим блоком оказался посвященный феномену так называемого интерактивного (электронного) 
романа в арабской литературе. Об этом важном явлении современной арабской литературы говорили на утреннем заседании 20 сентября 2018 г. Интерактивный (электронный, или цифровой) роман - это электронная информационная структура, размещаемая на некоем сайте. Электронный роман включает в себя как собственно текстовые элементы, так и изображения, видео- и звуковые файлы. Интерактивный роман - открытая структура: читатели, заходящие на сайт, где он размещен, имеют право включать в него свои собственные комментарии или дополнения, изменяя таким образом его содержание и структуру ${ }^{3}$.

Содержание выступлений, посвященных интерактивному роману, сводилось к следующему.

Интерактивный роман порожден университетской средой. Подобный роман, посвященный жизни городских люмпенов, сочиняется в Танжере. Автором проекта, в котором он осуществляется, является видный марокканский журналист и писатель 'Абд ал-Вахид Иститу (род. 1977) 4 .

Во время конференции участники не только работали, но и проводили «культурно организованный» досуг. Как и полагается на встрече людей, близких к литературе, главным «досуговым» мероприятием был вечер поэзии (ал-умсиййа аш-ши'риййа) 19 сентября (начался около 20.00). Все пришли в зал, где прежде проводилось заседание. Когда все расселись, к столу, где во время заседаний находился президиум, вышел марокканский литератор и сказал примерно следующее: «Мы собрались, чтобы послушать стихи друг друга. Поэзия - дело серьезное, но все же это развлечение». Далее ведущий вечера приглашал по одному участников форума, которые и знакомили аудиторию со своим поэтическим творчеством. Некоторые читали стихи, глядя на экраны смартфонов. Всего выступили семеро стихотворцев, в том числе и один из устроителей конференции, сотрудник Департамента по делам культуры эмирата Шарджа, египтянин, господин 'Абд ал-Фаттах Сабри. Двое выступавших прочитали стихи, сочиненные в традиционной форме; остальные пятеро - стихи в «новой» форме, белые, без рифмы. Видимо, такое соотношение «традиционализма» и «модернизма», проявившееся на этом поэтическом вечере, отражает общую тенденцию, существующую в современной арабской поэзии.

О большой значимости поэзии в современной арабской литературной и окололитературной среде свидетельствует не только поэтический вечер, но и кулуарные беседы с арабскими коллегами. Так, во время

${ }^{3}$ См.: Гипертекст. Материал из Википедии - свободной энциклопедии. Режим доступа: https://ru.wikipedia.org/wiki/\%D0\%93\%D0\%B8\%D0\%BF\%D0\%B5\%D1\%80\%D1\%82\% D0\%B5\%D0\%BA\%D1\%81\%D1\%82

4 'Абд ал-Вахид Иститу. Материал из Википедии - свободной энциклопедии. Режим доступа: https://ru.wikipedia.org/wiki/\%D0\%90\%D0\%B1\%D0\%B4_\%D0\%B0\%D0\%BB\%D 1\%8C-\%D0\%92\%D0\%B0\%D1\%85\%D0\%B8\%D0\%B4 
ужина я услышал от литературоведа и писателя из Иордании Ибрахима ас-Са“афин [2, с. 19] вот какой рассказ. «Я, - сказал доктор Ибрахим, в молодости учился в Каирском университете, на филологическом факультете. У нас был некий профессор, который преподавал методы литературоведческих исследований, весьма нервный и строгий человек. Мы, студенты, его обожали, однако боялись. Предстояло сдать ему сложный экзамен, а мне и моим товарищам по группе представлялось, что мы готовы не вполне достаточно. Чтобы смягчить сердце любимого преподавателя, я сочинил касиду в традиционном духе, в частности, зачин стихотворения описывал прощание с возлюбленной. Выслушав мой опус, профессор не сдержался, расплакался и поставил мне отличную оценку без экзамена. Прошло много лет. В 2005 г. отмечалась столетняя годовщина создания Отделения арабской словесности в Каирском университете. Я был приглашен на торжества. Руководителем Отделения оказалась дочь того профессора. Я прочитал ей касиду и рассказал ту давнюю историю. Стихотворение же помнил наизусть (да и сам текст у меня сохранился). Вообще же, - завершил доктор Ибрахим свой рассказ, - для души сочиняю довольно много стихов, а публикую мало».

Интересным опытом преподавания и литературного творчества была для доктора Ибрахима работа в качестве приглашенного профессора в университете штата Теннесси в США, где он читал курс лекций по истории арабской литературы. Оказалось, рассказывал он, что очень многие произведения арабской литературы, как прозаические, так и поэтические, переведены на английский язык. На литературном вечере, который проводился в университете, доктор Ибрахим читал свои стихи по-арабски и переводил их на английский. Со временем стал писать стихи по-английски. Одно из таких стихотворений было посвящено им столице штата Теннесси, городу Нашвиллу.

Это свидетельство не согласуется с мнениями других коллег, которые выказывали негативное отношение к Западу.

Происхождение элементов, составляющих традиционную касиду (этот жанр, как известно, сложился еще в доисламскую эпоху), интересует одного из бахрейнских участников конференции, литературоведа доктора Фахда Хусайна [2, с. 12]. В беседе со мною он высказал своеобразную точку зрения на причину того, что в большинстве муаллак (доисламских касид, которые считаются образцовыми в своем роде) [4, с. 70-97] в начале фигурирует покинутое бедуинское становище. Видимо, полагает он, такие зачины сочинялись заранее, а затем включались в текст вновь сочиняемого стихотворения.

20 сентября во второй половине дня участникам форума было предоставлено еще одно развлечение - экскурсия по достопримечательностям Рабата. Весьма бегло мы осмотрели мавзолей Мухаммада V, строительство которого было завершено в 1971 г., замок Шелла, основанный 
еще финикийцами, где сохранились не только памятники марокканской архитектуры мусульманской эпохи, но и многочисленные античные достопримечательности [5, p. 203]. Затем посетили недавно построенный яхт-клуб, что находится напротив мавзолея Мухаммада V, на другом берегу реки Уед Бу Регрег, впадающей в Средиземное море.

Наиболее интересными сведениями, почерпнутыми мною во время конференции, оказались те, которые я получил во время неформального общения с ее участниками.

Безусловно, более всего достойны внимания сами люди, с которыми довелось общаться. Среди них, думается, одной из самых ярких персон оказалась ливанская романистка 'Улвийа Субх [2, с. 56]. Мы познакомились с нею еще в аэропорту Касабланки и вместе ехали на присланном за нами автомобиле в Рабат. 'Улвийа тут же принялась рассказывать о себе: своим творчеством она взорвала все условности, присущие Арабскому миру, и поэтому ненавидима всеми режимами, которые правят в Арабских странах. Правда, по ее словам, в 2017 г. в ее честь в университете марокканского г. Тетуан (он находится на севере Мароккко) [5, p. 144-153] учредили особую премию и устроили чествование. Как бы то ни было, книги 'У. Субх - наиболее продаваемые в Арабском мире, так как они помогают арабским женщинам обрести самоуважение и бороться против гнета традиционных отношений. Самым знаменательным своим произведением 'У. Субх считает роман «Дунйа» (так зовут главную героиню). Муж Дунйи - искалеченный и парализованный полевой командир, который манипулирует женой, давая ей указания движениями глаз. В конце концов, Дунйа находит в себе силы уйти от своего мучителя. Через некоторое время после выхода романа в свет писательнице пришло письмо от некоей женщины. Та утверждала, что ее жизнь - это история Дунйи. Под влиянием романа читательница развелась с мужем-тираном, перестала носить покрывало и обрела свободу.

Поскольку я - человек из России и бывшего СССР, то 'У. Субх рассказала мне о том, как она еще в 1980 г. лечилась в Кунцевской больнице. Получить направление в эту советскую больницу она смогла благодаря связям с Ливанской коммунистической партией, персонально же ей помог известный ливанский философ-марксист Х. Мрувве (1910-1987)5. Советские врачи и медицинские сестры показались моей собеседнице чрезвычайно добрыми и внимательными. Так что теперь она пишет книгу воспоминаний о времени, проведенном в Кунцевской больнице.

Добрые воспоминания о Советском Союзе сохранил и литератор из Йемена Махмуд ал-'Аззани [2, с. 44]. В 1982-1987 гг. он учился на строительном факультете Белорусского политехнического института в Минске.

${ }^{5}$ Мрувве Хусейн. Википедия - свободная энциклопедия. Режим доступа: https:// ru.wikipedia.org/wiki/\%D0\%9C\%D1\%80\%D1\%83\%D0\%B2\%D0\%B2\%D0\%B5,_\%D0\%A5\% D1\%83\%D1\%81\%D0\%B5\%D0\%B9\%D0\%BD 
Минск, по его словам, - прекрасный город. Закончив обучение, мой собеседник жил на родине в Йемене до 1994 г., а затем эмигрировал в Великобританию. В Лондоне изучал управление деловыми компаниями.

Об отношении к России и русской культуре высказывались и многие другие мои собеседники. Позиция моих арабских коллег относительно нашей страны часто оказывалась тесно увязанной с их отношением к Западу в целом.

Одним из моих «информаторов» был журналист и литературовед, профессор Рабатского университета Анвар ал-Муртаджи. Он знаком с достижениями российской арабистики и знает имена главнейших ее представителей. Профессор Анвар побывал в Санкт-Петербурге, посетил Институт восточных рукописей РАН. Крупнейшим русским арабистом профессор Анвар справедливо полагает академика И. Ю. Крачковского, чей замечательный труд «Арабская географическая литература» $[6,2004]$ переведен на арабский язык 6 . Наш великий предшественник известен в Арабском мире также исследованием арабской поэтики ${ }^{7}$.

Большое достоинство современных российских арабистов, сравнительно с их западными, в частности французскими, коллегами профессор Анвар видит в том, что россияне гораздо лучше знают арабский язык, свободно говорят на нем, в то время как на Западе этот навык утерян. Французские арабисты, отметил он, стали плохо знать арабский язык. Они рассуждают об арабской истории и литературе по-французски, опираясь на уже написанные исследовательские труды или ранее выполненные переводы арабских источников, произносят арабские имена на французский манер. Это, считает он, выражение колониального комплекса. Об арабских ученых, так или иначе испытавших влияние французской культуры, они думают: «Мол, ты араб, знаешь свой арабский язык, - и довольно, сам изучай свою культуру».

В то же время мой собеседник отметил, что теперь стало проще заниматься научной работой, так как благодаря Интернету многие арабские рукописные тексты стали доступны, тогда как раньше для ознакомления с ними надо было отправляться в дальние путешествия.

Вместе с тем профессор Анвар полагает, что в исторической ретроспективе французское колониальное владычество принесло определенную пользу. Ведь не случайно первый президент Туниса Х. Бургиба ((1903-2000); занимал пост президента в 1957-1987 гг.) развивал образование на двух языках - арабском и французском. Он внедрял светские ценности, способствовал социализации женщин. Благодаря такой «про-

${ }^{6}$ Известно, что этот труд И. Ю. Крачковского был опубликован по-арабски в Каире в 1963 г. в переводе Салах ад-Дина Хашима.

7 Имеется в виду работа И. Ю. Крачковского «Арабская поэтика в IX в.» $[7,1956]$. 
западной» культурной политике даже тунисские исламисты оказались более умеренными, нежели в других странах. Тунис встретил «исламистскую революцию», имея значительный запас светскости. По этой причине страна сумела довольно быстро преодолеть последствия исламистского засилья.

С точки зрения профессора Высшей школы повышения квалификации преподавателей им. 'Абд ал-Малика ас-Са'ди (г. Тетуан), Йусуфа Фихри [2, с. 71], для Арабского мира в политическом отношении весьма важна современная Россия - она представляет собой хороший противовес Соединенным Штатам.

Так что для арабских интеллектуалов Россия важна и как страна с традиционно сильным научным востоковедением, и как великая политическая сила современности. Смею думать, что внимание и уважение, проявленные участниками конференции к моей скромной персоне, были вызваны этими двумя обстоятельствами - для них я был представителем крупнейшей востоковедной школы и гражданином мощного государства, исконного союзника арабов.

Напротив, Запад у тех моих коллег, с которыми мне довелось беседовать, вызывает раздражение.

По словам профессора и литератора из Тетуана 'Абд ар-Рахима Джайрана [2, с. 23], арабы зависят от Запада в теоретическом отношении, так как усваивают западные теории общественного и культурного развития. Он высказал мне свое убеждение в том, что с западной точки зрения арабская интеллигенция не вправе создавать собственные теории, что это является следствием экономической и технологической несамостоятельности Арабского мира. Да, с горечью сказал профессор Джайран, мы имеем право на самостоятельное творчество в сфере фольклора и литературы, но не имеем права самостоятельно осмыслять результаты нашего творчества. Он считает, что в своих статьях, выложенных в Фейсбуке, он выражает новое прочтение арабского фольклора, но эти публикации пока не получили должного резонанса.

Как бы то ни было, но родная культура, ее истоки и судьбы имеют для арабских литераторов первостатейное значение.

Профессор Й. Фихри рассказывал мне, что культурная ситуация в современном Марокко отличается высокой степенью разнообразия. В бытовой культуре марокканцев, считает он, сосуществуют две тенденции - традиционная и европейская. В одной и той же семье одна сестра может одеваться по-европейски, а другая - традиционно. Причем девушка, носящая традиционную одежду, не всегда оказывается нравственной. В одном и том же доме часто одна комната может быть обставлена по-европейски, а другая - в исконной марокканской манере.

Другой аспект современной культурной ситуации в Марокко - это наличие в стране значительного контингента француженок, вышедших 
замуж за марокканцев. Чаще всего, отметил профессор Й. Фихри, «французские» жены весьма органично встраиваются в марокканское общество, уважают его установления. В целом же, полагает он, в современном Арабском мире культура стала не ценностью и целью, но средством решения тех или иных политических задач. Именно так относился к культуре руководитель Ливии М. Каддафи ((ок. 1940-2011); стоял во главе Ливии в 1969-2011 гг.). Таким же образом использовал установления традиционной марокканской культуры прежний король Хасан II ((1929-1999); король Марокко в 1961-1999 гг.). Осознавая, насколько марокканцы почитают мечети, возведенные в традиционном национальном архитектурном стиле, он использовал возведение Большой мечети, носящей его имя, в Касабланке [5, р. 220] в качестве средства, объединяющего население всей страны. Монарх говорил: «Пусть каждый марокканец пожертвует хоть один динар». Богатые люди жертвовали охотно, а бедные были недовольны, потому что считали такие поборы незаконными и обременительными.

Мой марокканский собеседник высказал мнение, что Россия как раз дает плодотворный пример сочетания культуры и политики. Он считает важным, что российский министр иностранных дел С. В. Лавров - образованный человек, пишет стихи и сочиняет рассказы. Такое отношение к государственному деятелю в Арабском мире весьма показательно, так как многие деятели арабо-мусульманской истории были любителями изящной словесности; арабо-мусульманское историческое предание как жанр приписывает многим из них сочинение стихов [8, с. 130-133].

Конечно, мои собеседники - люди, безусловно, современные. Однако для них чрезвычайно важна традиционная арабо-мусульманская культура, сложившаяся в пору расцвета арабо-мусульманской цивилизации и являющаяся для них не только интеллектуальной пищей, порой - сферой профессиональных занятий и источником эстетического наслаждения, но и символом былого могущества Арабского мира.

Так, Й. Фихри в начале профессиональной деятельности занимался исследованием некоей редкой старинной рукописи. Работа зашла настолько далеко, что он даже подготовил весьма подробный комментарий к будущему ее изданию. Однако позже он, как сам мне признался, по неизвестной причине оставил это занятие и переключился на изучение современного марокканского романа.

В отличие от Й. Фихри, другой марокканский коллега, А. ал-Муртаджи, сохранил к родной традиционной словесности не только любительский, но и профессиональный интерес. Любимым героем традиционной арабской культуры для него является ал-Хасан б. Мухаммад ал-Ваззан (ок. 1492-1552), магрибинский ученый-географ, который ок. 1520 г. попал в плен к сицилийским корсарам, был подарен ими папе Льву X (1513-1521; в миру Джованни Медичи). 
Он был известен также как Лев Африканский (внешне принял христианство под именем Джованни Леоне), преподавал арабский язык в Риме и Болонье, в 1526 г. перевел с арабского оригинала на итальянский (а возможно, сразу написал его на этом языке) собственное сочинение «Описание Африки», впоследствии неоднократно издававшееся в Европе. Около 1528 г. вернулся в одну из «стран ислама»- Тунис, где и скончался в лоне родной религии [6, с. 445-450, 454] ${ }^{8}$.

А. ал-Муртаджи написал о Льве Африканском пьесу и переиздал сочинение марокканского факиха, Мухаммада ал-Махди ал-Хаджви (1903-1968), посвященное Льву Африканскому9. Интерес к сочинению ал-Хаджви у профессора ал-Муртаджи был вызван тем обстоятельством, что он в свое время учился в знаменитой мечети ал-Каравиййин [11] в старинном марокканском городе Фесе [5, р. 264-292], а там некогда шейх ал-Хаджви преподавал ученикам, собиравшимся вокруг него в «кружок» (халака (халка)) ${ }^{10}$. Там же, считает профессор Анвар, учился и папа Сильвестр II (999-1003; в миру Герберт Аврилакский; родился в 940-х гг.), который был одним из первых европейских востоковедов $[13, \text { с. } 453-454]^{11}$.

В труде ал-Хаджви моему собеседнику особенно понравился пассаж, в котором говорится, что Лев Африканский не отрекся от ислама, «хотя ему было всего 17 лет, когда он оказался в плену у христиан» (на самом деле ему было в это время около 28 лет. - Д. М.), но использовал принцип такиййи [10, с. 22]. Находясь под покровительством папы Льва Х, продолжил профессор ал-Муртаджи, Лев Африканский быстро выучил итальянский и латинский языки, так как уже знал испанский (ведь его семья была родом из Мусульманской Испании), и осуществил перевод на латинский язык первой главы Корана - «Фатихи». Описание Африки, данное Львом Африканским, весьма точное, хотя он, как полагает профессор Анвар, не обладал никакими заранее подготовленными материалами. Точны даже приводимые им расстояния между африканскими городами - это проверили уже в XX в.

8 См. также издание труда Льва Африканского в русском переводе: [9].

9 Мухаммада ал-Махди ал-Хаджви упоминает И. Ю. Крачковский [6, с. 445, примеч. 2]. См. книгу ал-Хаджви: [10].

10 Халака (халка) - совокупность учеников, собравшихся вокруг преподавателя; весьма широко распространенная традиционная форма преподавания в мусульманском мире $[12$, c. 186].

11 Думается, что сведения об учебе будущего римского первосвященника в мечети ал-Каравиййин - местная легенда, подтверждающая выдающуюся роль этого религиозного учреждения и центра традиционного образования. С именем будущего папы Сильвестра II связано также предание о том, что он якобы стал учеником некоего араба-чернокнижника в Кордове, соблазнил его дочь и бежал, похитив книги своего наставника [14, с. 83]. Так что Сильвестр II, безусловно, персона легендарная. 
Благодаря достоверным сведениям, сообщенным ал-Хасаном б. Мухаммадом ал-Ваззаном, европейцы сумели быстро подчинить себе Африканский континент. B XVI-XVII вв. Лев Африканский был столь знаменит, что о нем упоминает У. Шекспир в «Венецианском купце» ${ }^{12}$.

И в выступлениях, и в кулуарных беседах более всего внимания уделялось другому феномену традиционной арабской культуры - «Книге тысячи и одной ночи».

Так, на вечернем заседании 18 сентября литературовед из Саудовской Аравии Фахд Хусайн отметил, что в современном арабском романе чаще всего встречаются отсылки к таким источникам родной традиционной словесности, как Коран, макамы и «Книга тысячи и одной ночи». В некоторых романах прослеживаются суфийские мотивы. 19 сентября на утреннем заседании тунисская писательница Хайат ар-Райис [2, с. 49], говоря о значении литературной критики для развития современного романного творчества, отметила, что главная рассказчица в «Тысяче и одной ночи», Шахразада, не имела «литературных учителей», подобных современным критикам, однако сумела создать великое повествование, сравнимое с нынешним романом.

Буквально за час до того, как я уехал в аэропорт, чтобы отправиться домой, я стал не только свидетелем, но и участником дискуссии о «Тысяче и одной ночи», которая разгорелась в фойе нашего отеля.

Коллега из Бахрейна, д-р Фахд Хусайн, спросил моего мнения - арабское это произведение или чужеземное? Я ответил, что этот памятник безусловно, арабское произведение, однако истоки его индийские и иранские. Арабы сумели его арабизировать, то есть сделать понятным арабским читателям и любимым ими. Д-р Ф. Хусайн же возразил: «Однако имена Шахразада, Шахрийар и другие явно не арабские». «Ну и что, ответил я. - Книга-то получилась арабской».

Другой участник разговора, марокканский литературовед д-р 'Абд ал-Латиф Махфуз [2], отметил, что к ним, в ал-Магриб, «Тысяча и одна ночь» пришла с востока Арабского мира.

Д-р Ф. Хусайн, продолжая разговор, сказал, что, возникнув в странах ал-Машрика, «Книга...» явилась результатом труда многих переписчиков, которые вставляли в нее всевозможные истории. Однако другой важный вопрос - это вопрос о возникновении памятника. Кто записывал

12 Подтверждения этому суждению нам обнаружить не удалось. Тем не менее идея об отражении личности Льва Африканского в творчестве гениального английского драматурга, по всей видимости, довольно популярна в кругах арабской интеллигенции. Думается, что как раз об этом свидетельствует суждение американского журналиста Т. Верде, высказанное им в статье о Льве Африканском. Статья же была опубликована в журнале Saudi Aramco World (ныне называется Aramco World), издаваемом саудовской национальной нефтяной компанией АРАМКО в Хьюстоне (США); журнал выходит раз в два месяца. Т. Верде утверждает, что личность Льва Африканского повлияла на формирование образа Отелло в одноименной трагедии У. Шекспира [5, р. 3]. 
истории, рассказанные Шахразадой? Мог ли Шахрийар слушать речи Шахразады всю ночь? Когда же он спал?

Таким образом, бахрейнский коллега воспринимает рамочную структуру памятника, исходя из позиций нашего литературоведения, довольно наивно, видя в ней не воплощение фольклорного сюжета, не некий литературный прием, но вполне саму по себе реальную историю.

Тут свое мнение по поводу бытования и изучения «Тысячи и одной ночи» в Арабском мире высказал коллега из Египта. Он подчеркнул, что в Европе исследованием памятника начали заниматься раньше, чем у него на родине, в Арабском мире. Сами арабы узнали об этом собрании сказок благодаря усилиям первого переводчика «Книги...» в Европе А. Галлана (1646-1715). Ему удалось получить изначальную рукопись, которую он и стал переводить в соответствии со вкусами своей эпохи.

Вновь вступив в разговор, д-р 'Абд ал-Латиф Махфуз отметил, что «Книгой...» довольно рано заинтересовались детские писатели и стали переделывать ее для подрастающего поколения - ведь джинны и джиннии, волшебники и волшебницы, всевозможные превращения и прочие чудеса оказывались, при соответствующей переделке, весьма привлекательными для юных читателей.

Вместе с тем, возразил коллега из Египта, в собрании сказок Шахразады много реалистической правды. Например, известная сказка и Медном Городе отражает впечатления арабов-мусульман от традиционной североафриканской архитектуры.

Однажды, продолжил египетский литературовед, его пригласили прочитать курс лекций о «Тысяче и одной ночи» в Чикагском университете. Среди прочего он высказал следующую мысль: жена царя Шахрийара перевернула социальную пирамиду - вместо белокожего царя она поставила темнокожего раба (иными словами, сделала царем невольника-африканца). Такая идея весьма пришлась по вкусу американской университетской аудитории. Другая функция Шахразады, по мнению египетского коллеги, заключается в том, что она спасительница. Ведь она рассказывает царю Шахрийару истории, чтобы спасти себя самое. Однако тем самым она избавляет от смерти и других молодых женщин того государства.

Подобные рассуждения также весьма далеки от установлений нашей отечественной и мировой литературоведческой и фольклористической школ ${ }^{13}$.

Таким образом, мои впечатления от участия в этом форуме были весьма богаты и разнообразны. Однако не все его участники оказались согласны со мной. По мнению некоей писательницы, конференция

${ }^{13}$ См. изложение современных научных воззрений на происхождение и структуру «Книги тысячи и одной ночи» [15]. 
2018 г. оказалась неудачной. На ней говорили о тех же самых романах, которые анализируются из года в год, упоминались все те же самые имена. В этом году заговорили о так называемом электронном романе, сказала она, но какое отношение это имеет к моему творчеству, я работаю в традиционной манере и настороженно отношусь к экспериментам в сфере литературы.

Словом, 15-я Шарджийская встреча по проблемам развития арабской художественной прозы, как и большинство других форумов, не могла прийтись по вкусу всем ее участникам. Однако данное обстоятельство не мешает этому продолжающемуся форуму быть заметным явлением и в арабской литературной жизни, и в арабской культуре в целом.

\section{Аитература}

1. Мелкумян Е. С. История государств Арабского залива (Бахрейн, Катар, Кувейт, Объединенные Арабские Эмираты, Оман) в XX - начале XXI в.). М.: Фонд русско-арабских исследований и информации; Институт востоковедения $\mathrm{PAH}$; 2016.

2. Мултака аш-Шарика ли-с-сард. Ад-Даура ал-хамиса'ашара. Ар-Ривайа ал-джадида: ат-тахаввулат ва джамалиййат аш-шакл ар-рива'и. 18-20 сабтамбар 2018. Ал-Мамлака ал-Магрибиййа. Ар-Рибат. Ал-Имарат ал-Арабиййа ал-Муттахида. Да'ират ас-сакафа. Аш-Шарика - ал-Мамлака ал-Магрибиййа. Визарат ас-сакафа ва-л-иттисал; [2018]. (На араб. яз.)

3. Ар-Ривайа ал-джадида: тахаввулат ва джамалиййат аш-шакл ар-рива'и. Вака'и' Мултака аш-Шарика ал-хамис 'ашар ли-с-сард. Б.м., б.г. (Новый роман: изменения, [произошедшие] в форме и [ее] эстетические особенности. Труды Пятнадцатого Шарджийского форума, [посвященного] прозе).

4. Фильштинский И. М. История арабской литературы. V- начало Х века. М.: ГРВЛ; 1985.

5. Vinon R. Maroc 2003/2004. Paris: Prisma Presse; 2003.

6. Крачковский И. Ю. Арабская географическая литература. М.: Восточная литература; 2004.

7. Крачковский И. Ю. Арабская поэтика в IX в. В: Крачковский И. Ю. Избранные сочинения. М.; Л.: Изд-во Академии наук СССР; 1956. Т. 2. С. 360-372.

8. Микульский Д. В. Арабо-мусульманская культура в сочинении ал-Мас'уди «Золотые копи и россыпи самоцветов» («Мурудж аз-захаб ва ма'адин ал-джаухар»). Х век. М.: Восточная литература; 2006.

9. Лев Африканский. Африка - третья часть света. Описание Африки и достопримечательностей, которые в ней есть. Л.: Наука; 1983.

10. Хайат ал-Ваззан ал-Фаси ва асарух. Та'лиф Мухаммад ал-Махди ал-Хаджви... Рабат. Ал-Матба'а ал-иктисадиййа ли-сахибиха Мустафа б. 'Абдаллах; 1935-1354. (На араб. яз.)

11. Deverdun G. Al-Karawiyyin. In: The Encyclopaedia of Islam. New Edition. Vol. 4. Third Impression. Leiden: E.J. Brill; 1997. P. 632-635. 
12. Халидов А. Б. Арабские рукописи и арабская рукописная традиция. М.: Наука; ГРВЛ; 1985.

13. Брокгауз Ф. А., Ефрон И. А. Энциклопедический словарь. СПб.: ТипоЛитография И. А. Ефрона и Ф. А. Брокгауза; 1892. Т. 8.

14. Монтгомери Уотт У. Влияние ислама на средневековую Европу. М.: Наука; ГРВЛ; 1976.

15. Marzolph U. Arabian Nights. In: The Encyclopaedia of Islam Three. Preview. Leiden: Brill; 2007. P. 30-39.

\section{References}

1. Melkumyan E. S. History of the Gulf States (Bahrein, Qatar, Kuwait, United Arabic Emirates, Oman) in the 20 $0^{\text {th }}$ - beginning of the $21^{\text {st }}$ cent. Moscow: Fond russko-arabskikh issledovanii i informatsii; Institute of Oriental Studies, Russian Academy of Sciences; 2016.

2. Multaqa ash-Shariqa li-s-sard. Ad-Dawra al-khamisa 'ashara. Ar-Riwaya al-djadida: at-tahawwulat wa-djamaliyyat ash-shakl ar-riwa'i. 18-20 sabtambr 2018. Al-mamlaka al-maghribiyya. Ar-Ribat. Al-Imarat al-Arabiyya al-Muttahida. Da'irat ath-thaqafa. Ash-Shariqa - al-Mamlaka al-Maghribiyya. Wizarat ath-thaqafa wa-l-ittisal [2018] = The Sharjah. Meeting regarding the writings in Prose. The 15 th Session: "A modern Novel - The specific aesthetic features regarding the form and changes. $18^{\text {th }}-20^{\text {th }}$ September 2018. The Kingdom of Marocco. Rabat. United Arabic Emirates. The Office of Culture. Sharjah. The Kingdom of Marocco. The Ministry of Culture and Coordination. 2018. (In Arabic.)

3. Ar-Riwaya al-djadida: tahawwulat wa-djamaliyyat ash-shakl ar-riwa'i. Waqa'i Multaqa ash-Shariqah al-khamis ‘ashar li-s-sard. B.t. B.m. (The Modern Novel. The changes in the form and its aesthetical features. Proceedings of the $15^{\text {th }}$ Sharjah Meeting regarding the Prose. No date, no place.) (In Arabic).

4. Filshtinsky I. M. History of Arabic Literature $5^{\text {th }}-$ beginning of the $10^{\text {th }}$ cent. Moscow: GRVL; 1985. (In Russ.)

5. Vinon R. Maroc 2003/2004. Paris: Prisma Presse; 2003.

6. Krachkovsky I. Yu. The Geographical Literature of the Arabs. Moscow: Vostochnaya literatura; 2004. (In Russ.)

7. Krachkovsky I. Yu. The Arabic poetics in the $9^{\text {th }}$ cent. In: Krachkovsky I. Yu. Collected Works. Moscow; Leningrad: USSR Academy of Sciences; 1956. Vol. 2, pp. 360-372. (In Russ.)

8. Mikulsky D. V. Arabic Islamic culture as reflected in the "Murudj adh-Dhahab wa-Ma 'adin al-Djawhar" by al-Mas'udi (10 th cent.) Moscow: Vostochnaya literatura; 2006. (In Russ.)

9. Lev Afrikanskii. The Third Part of the World - Africa. A description of Africa and all the sightseeings that it has. Leningrad: Nauka; 1983. (In Russ.)

10. Hayat al-Wazan al-Fasi wa-atharuh. Ta'lif Muhammad al-Mahdi al-Hadjwi. Rabat. Al-Matba`a al-iqtisadiyya li-sahibiha Mustafa b. `Abdallah 1935/1354 = Al-Wazzan al-Fasi, his Life and his works. By Muhammad al-Mahdi al-Hadjwi. Rabat. Private economic Publishing House of Mustafa b. `Abdallah. 1935-1354. (In Arabic). 
11. Deverdun G. Al-Karawiyyin. In: The Encyclopaedia of Islam. New Edition. Vol. 4. Third Impression. Leiden: E.J. Brill; 1997, pp. 632-635.

12. Khalidov A. B. Arabic Manuscripts and the Arabic manuscript tradition. Moscow: Nauka; GRVL; 1985. (In Russ.)

13. Brokgauz F. A. Efron I. A. Encyclopaedic Dictionary. St Petersburg: TipoLitografiya I. A. Efrona i F. A. Brokgauza; 1892. Vol. 8. (In Russ.)

14. Montgomery Watt W. The Influence of Islam on Medieval Europe. Edinburgh University Press; 1972.

15. Marzolph U. Arabian Nights. The Encyclopaedia of Islam Three. Preview. Leiden: Brill; 2007, pp. 30-39.

\section{Информация об авторе}

Микульский Дмитрий Валентинович, доктор исторических наук, главный научный сотрудник Института востоковедения РАН, г. Москва, Российская Федерация.

\section{Раскрытие информации} о конфликте интересов Автор заявляет об отсутствии конфликта интересов.

\section{Информация о статье}

Поступила в редакцию: 21 октября 2019 г. Одобрена рецензентами: 31 октября 2019 г.

Принята к публикации: 5 ноября 2019 г.
\end{abstract}

Information about the author

Dmitry V. Mikulsky, Dr. Sci. (Hist.), Prof., Senior Researcher, Institute of Oriental Studies, Russian Academy of Sciences, Moscow, Russian Federation.

\section{Conflicts of Interest Disclosure}

The author declares that there is no conflict of interest.

\section{Article info}

Received: October 21, 2019

Reviewed: October 31, 2019

Accepted: November 5, 2019 